\title{
Comparison of efficacy between incretin-based therapies for type 2 diabetes mellitus
}

\author{
Kaustubh Nisal ${ }^{1}$, Ram Kela ${ }^{1}$, Kamlesh Khunti ${ }^{2}$ and Melanie J Davies ${ }^{1,3^{*}}$
}

\begin{abstract}
Type 2 diabetes mellitus is widely prevalent and is often coexistent with obesity. Many of the available treatment options have side effects such as weight gain which often affect patient's willingness to continue the treatment. Effective weight loss, lack of significant hypoglycaemia, and favourable cardiometabolic profile make Incretin based therapies an attractive treatment option for type 2 diabetes. Incretin based therapies are available as either incretin mimetics (also called GLP-1 agonists) or incretin enhancers (DPP-4 inhibitors). Although agents in both these classes of incretin based therapy are effective through a common GLP-1 pathway, there are many differences amongst them including the route of administration, frequency of administration, effects on body weight, extent of glycaemic improvement. There are several trials evaluating these individual incretin based agents either as monotherapy or in combination with other anti-diabetic agents, however very few have looked into direct comparison amongst the agents in these two classes. This review is aimed to look at important mechanistic differences between incretin mimetics and enhancers through direct comparison trials and impact of these differences on biochemical, metabolic and patient satisfaction parameters.
\end{abstract}

Keywords: GLP-1 analogues, GLP-1 agonists, DPP-4 inhibitors, incretins, head to head comparison, patient satisfaction

\section{Review Introduction}

The prevalence of type- 2 diabetes mellitus (T2DM) is rapidly increasing worldwide. The International Diabetes Federation (IDF) estimates the current prevalence of diabetes at around 366 million which is estimated to increase to 552 million cases of diabetes and 398 million cases of impaired glucose tolerance (IGT) by 2030 [1]. Similarly, there has been an uptrend in adiposity worldwide [2]. The National Obesity Observatory data estimates the prevalence of obesity in the UK at $23 \%$, while $61 \%$ of adults are overweight [3]. The majority of patients with T2DM are obese [4] and many of the current therapeutic options for management of T2DM can cause further weight gain $[5,6]$. Concerns about weight gain adversely affect patients' willingness to begin and continue treatment with glucoselowering medications, such as thiazolidinediones (TZDs), insulin, and sulfonylureas (SU) [7]. Often the patient's quality of life can be negatively affected by the underlying disease process and its complications, such as polypharmacy, weight gain, hypoglycemia and micro- and macrovascular complications [8]. Recently introduced incretin based therapies appear to offer advantages over conventional therapies by either keeping the weight steady or even achieving weight loss and limiting hypoglycemia, while achieving effective glycemic control. This review examines the comparisons between two classes of incretin based therapies, dipeptidyl peptidase 4 (DPP-4) inhibitors (incretin enhancers) and glucagon-like peptide 1 (GLP-1) agonists (incretin mimetics). Although use of incretin based therapies for T2DM has been reviewed before [9-11], this article focuses on data from head to head

\footnotetext{
* Correspondence: melanie.davies@uhl-tr.nhs.uk

'Department of Diabetes and Endocrinology, University Hospitals of Leicester NHS Trust, Leicester Royal infirmary, Infirmary Square, Leicester LE1 5WW, UK

Full list of author information is available at the end of the article
} 
comparative trials analyzing efficacy, tolerability and safety profiles between the agents from these two classes.

\section{Physiology of incretins}

The classic 'incretin effect' refers to the observation that oral glucose elicits a higher insulin response compared to intravenous glucose at similar plasma glucose concentrations. GLP-1 and glucose-dependent insulinotropic polypeptide (GIP), two major incretin hormones that are secreted into the circulation by 'L' and ' $K$ ' cells of the small intestine, respectively, are responsible for $50 \%$ to $70 \%$ of glucose dependent insulin release [12-14]. Apart from insulinotropic effects, GLP-1 also suppresses glucagon release, reduces hepatic gluconeogenesis, delays gastric emptying and reduces food intake by promoting satiety [15]. The impaired incretin effect in patients with T2DM is thought to be multifactorial. Reduced postprandial GLP-1 response $[16,17]$ and a reduced insulinotropic response [18] are contributing factors. In a study comparing healthy subjects with patients with T2DM, lack of the incretin effect, in spite of comparable GLP-1 as well as GIP secretion, was observed [19]. Administration of GLP-1 subcutaneously over six weeks in patients with T2DM has been shown to improve glycemic control, insulin sensitivity, and beta cell function along with reduced gastric emptying and reduction in bodyweight [15]. However, GLP-1 secretion is not always reduced and may be normal in patients with T2DM $[20,21]$. Age, body weight, fasting glucagon and Non-Esterified Fatty Acids (NEFA) concentrations are some of the factors thought to affect the incretin response [21].

\section{Incretin based therapies}

Due to various favorable cardiometabolic and insulinotropic effects, GLP-1 is a very attractive candidate as a therapeutic invention in management of T2DM. Native GLP-1 has a very short half-life of a few minutes as it is broken down by endopeptidase enzymes such as DPP- 4 which has a ubiquitous presence in the human body [22-24]. As the native GLP-1 molecule is unsuitable for routine clinical use, stimulation of GLP-1 receptors either by administration of GLP-1 agonists or restoring the endogenous GLP1 pool by inhibiting its DPP-4 mediated breakdown are the two approaches used to obtain or maintain high levels of GLP-1[14].

\section{Incretin mimetics}

GLP-1 agonists mimicking endogenous GLP-1 in their pharmacokinetic and pharmacological properties are termed incretin mimetics. These are modified GLP-1 molecules and are resistant to DPP-4 induced degradation. Exenatide, a molecule originally isolated from the saliva of the Heloderma suspectum lizard (Exendin-4) was the first GLP-1 agonist to become available for clinical use and was approved by the US Food and Drug Administration (FDA) in April 2005 and by the European Medicine Agency (EMA) in November 2006 [25,26].

Liraglutide is the first human GLP-1 analogue with 97\% amino acids sequence homology with native GLP-1; fatty chain addition to its molecule prolongs its half-life to 13 hours [27]. Recently, a long acting once weekly preparation of exenatide (Bydureon) at a dose of $2 \mathrm{mg}$ has been approved for clinical use by the EMA in Europe [28].

\section{Incretin enhancers}

DPP-4 inhibitors are termed incretin enhancers as they prolong the half-life and availability of endogenous GLP-1 by inhibiting DPP-4. Sitagliptin was the first DPP-4 inhibitor approved for clinical use in October 2006 followed by vildagliptin in Europe and saxagliptin in the US markets [29]. Alogliptin has market approval in Japan, while linagliptin has recently gained approval for clinical use in the US as well as Europe.

Currently, other GLP-1 agonists (for example, lixisenatide and albiglutide) and DPP-4 inhibitors are at various stages of development and in clinical trials programs. Taspoglutide is another once weekly human GLP-1 analogue in development but further trials have been suspended in the late stages due to agent specific hypersentivity reactions.

\section{Comparisons between incretin mimetics (GLP-1 agonists) and incretin enhancers (DPP-4 inhibitors)}

Agents in both these classes have been studied as monotherapy or in combination with other anti-diabetic medications. DPP-4 inhibitors are administered orally, once a day as compared to GLP-1 agonists which are administered subcutaneously, once or twice a day or more recently once a week. GLP-1 agonists slow gastric emptying in addition to a reduction in appetite but DPP-4 inhibitors do not seem to have these effects [30]. In general, the observation is that GLP-1 agonists have been found to be more effective in glycemic management and weight reduction compared to DPP-4 inhibitors. However, there are a limited number of head to head studies directly comparing the effects of DPP- 4 inhibitors and GLP-1 agonists. The first data suggesting key differences between DPP-4 inhibitors and GLP-1 agonists comes from an initial short term proof of concept study suggesting important mechanistic differences between exenatide twice a day (bid) and sitagliptin [31]. Since then, longer term randomized control trials (RCTs) have compared these two classes of therapeutic agents as summarized in Table 1.

\section{The 'proof of concept' study}

In a short double blind, double dummy, cross-over study involving 61 patients with metformin treated T2DM, a twoweek therapy with exenatide ( $5 \mathrm{mcg}$ bid for the first week, increasing to $10 \mathrm{mcg}$ bid for the second week) was associated with greater improvement in two-hour postprandial 
Table 1 Overview of head to head comparisons amongst GLP-1 analogues and DPP-4 inhibitors.

\begin{tabular}{|c|c|c|c|c|c|}
\hline Study & Duration & Type & GLP-1 analogue & DPP-4 inhibitor & $\begin{array}{l}\text { Co- existing } \\
\text { therapy }\end{array}$ \\
\hline $\begin{array}{c}\text { DeFronzo et al. } \\
{[31]}\end{array}$ & 4 weeks & $\begin{array}{l}\text { Double blind, double } \\
\text { dummy, cross over }\end{array}$ & $\begin{array}{c}\text { Exenatide } 5 \mathrm{mcg} \text { twice daily for } 1^{\text {st }} \text { week followed by } \\
10 \mathrm{mcg} \text { twice daily for } 2^{\text {nd }} \text { week }\end{array}$ & $\begin{array}{l}\text { Sitagliptin } 100 \mathrm{mg} \\
\text { once daily }\end{array}$ & Metformin \\
\hline Berg et al. [32] & 8 weeks & $\begin{array}{l}\text { Double blind, double } \\
\text { dummy, cross over }\end{array}$ & Exenatide $10 \mathrm{mcg}$ twice daily & $\begin{array}{l}\text { Sitagliptin } 100 \mathrm{mg} \\
\text { once daily }\end{array}$ & none \\
\hline $\begin{array}{l}\text { 1860-Lira DPP4 } \\
\text { [33] }\end{array}$ & 26 weeks & Open label parallel group & Liraglutide $1.2 \mathrm{mg}$ and Liraglutide $1.8 \mathrm{mg}$ & $\begin{array}{l}\text { Sitagliptin } 100 \mathrm{mg} \\
\text { once daily }\end{array}$ & Metformin \\
\hline DURATION 2 [35] & 26 weeks & Double dummy & Exenatide QW 2 mg once weekly & $\begin{array}{l}\text { Sitagliptin } 100 \mathrm{mg} \\
\text { once daily }\end{array}$ & Metformin \\
\hline DURATION 4 [37] & 26 weeks & Double dummy & Exenatide QW 2 mg once weekly & $\begin{array}{l}\text { Sitagliptin } 100 \mathrm{mg} \\
\text { once daily }\end{array}$ & none \\
\hline T-emerge 4 [39] & 24 weeks & Double dummy & Taspoglutide $10 \mathrm{mg}$ and $20 \mathrm{mg}$ weekly & $\begin{array}{l}\text { Sitagliptin } 100 \mathrm{mg} \\
\text { once daily }\end{array}$ & Metformin \\
\hline $\begin{array}{l}\text { 1860- Lira DPP4 } \\
\text { extension [34] }\end{array}$ & 52 weeks & Open label parallel group & Exenatide $10 \mathrm{mcg}$ twice daily & $\begin{array}{l}\text { Sitagliptin } 100 \mathrm{mg} \\
\text { once daily }\end{array}$ & Metformin \\
\hline
\end{tabular}

DDP-4, dipeptidyl peptidase 4; GLP-1, glucagon-like peptide 1

glucose (PPG) as compared to that obtained with two weeks of therapy with sitagliptin $100 \mathrm{mg}$ once daily [31]. More importantly, sitagliptin-treated patients noticed further improvement in PPG levels after changing over to exenatide suggesting the superiority of exenatide in improving postprandial hyperglycemia, an effect of increased postprandial insulin release associated with GLP-1 receptor agonists. There was no statistically significant difference in the improvement achieved by both agents in fasting plasma glucose (FPG). The differential mechanistic effects are summarized in Table 2.

Patients' gastric emptying rates were also assessed using $1,000 \mathrm{mg}$ of an oral liquid acetaminophen preparation. Exenatide significantly slowed gastric emptying compared to sitagliptin $(P=<0.0001)$. Exenatide-treated patients were also found to exhibit a reduction in their calorie intake as assessed by ad libitum meals. There was reduced calorie intake averaging $134 \mathrm{kcal}$ less in the exenatide-treated group compared to the sitagliptin-treated group. Due to the variability of the calorie intake, median caloric intake was assessed which showed a similar trend (exenatide: $-138 \mathrm{kcal}$ versus sitagliptin: $+63 \mathrm{kcal})$.

During this two-week trial the mean postprandial glucagon concentration relative to baseline was reduced in both treatment groups; the reduction in postprandial glucagon following exenatide was significantly greater compared to sitagliptin $(P=<0.0011)$. There was an increase in the insulinogenic index of insulin secretion with exenatide compared to sitagliptin (ratio exenatide to sitagliptin: 1.50 $+/-0.26, P=0.0239$ ). Nausea was the predominant side effect, experienced by $34 \%$ of patients treated with exenatide and $12 \%$ of patients treated with sitagliptin. Vomiting was experienced by $24 \%$ of patients treated with exenatide and $3 \%$ of patients treated with sitagliptin [31].

Table 2 Mechanistic differences between GLP-1 agonist exenatide and DPP-4 inhibitor sitagliptin [31].

\begin{tabular}{|c|c|c|c|c|}
\hline & & Sitagliptin & Exenatide & Significance \\
\hline Change in FPG (mmol/l) & & $1.04+/-0.2$ & $0.83+/-0.2$ & $P=0.3234$ \\
\hline Change in PPG (mmol/l) & & $2.0+/-0.3$ & $6.26+/-0.3$ & $P<0.0001^{*}$ \\
\hline Insulinogenic index & & Yes & Yes- significantly more than sitagliptin & $P=0.0239^{*}$ \\
\hline Acute Insulin secretion & & Yes & Yes- significantly more than sitagliptin & $P=0.0017^{*}$ \\
\hline Reduction in post -prandial glucagon & & Yes & Yes- significantly more than sitagliptin & $P=0.0011^{*}$ \\
\hline Reduction in gastric emptying & & none & Yes- significantly more than sitagliptin & $P<0.0001^{*}$ \\
\hline \multirow[t]{3}{*}{ Six point SMBG excursions } & Post breakfast & & Yes- significantly less than sitagliptin & $P=0.0016^{*}$ \\
\hline & Post lunch & & Similar to Sitagliptin & $P=0.07849$ \\
\hline & Post dinner & & Yes- significantly less than sitagliptin & $P=0.038^{*}$ \\
\hline Reduction in body weight (kg) & & $0.3+/-0.2$ & $0.8+/-0.2$ & $P=0.0056^{*}$ \\
\hline Decrement in calorie intake & & none & Yes- significantly more than sitagliptin & $P=0.0227^{*}$ \\
\hline Reduction in post-prandial triglyceride levels & & yes & Yes- significantly more than sitagliptin & $P=0.018^{*}$ \\
\hline Nausea & & $12 \%$ & $34 \%$ & \\
\hline Vomiting & & $3 \%$ & $24 \%$ & \\
\hline
\end{tabular}

*Statistically significant. DDP-4, dipeptidyl peptidase 4; FPG, fasting plasma glucose; GLP-1, glucagon-like peptide 1; PPG, postprandial glucose; SMBG, selfmonitoring blood glucose 
A more recent study comparing both of the above therapies given for eight weeks in patients with T2DM (baseline hemoglobin A1c (HbA1c) of $8.3 \pm 1.0 \%$ and body mass index of $35 \pm 5 \mathrm{~kg} / \mathrm{m} 2$ ) revealed a reduction in postprandial glucagon secretion and an improvement in a homeostasis model assessment of beta-cell function (HOMA-B) with exenatide $10 \mathrm{mcg}$ bid as well as sitagliptin $100 \mathrm{mg}$ daily; however, the improvement was significantly more in exenatide treated patients compared to the sitagliptin treated group [32]. Both exenatide and sitagliptin therapies resulted in an improvement in two-hour PPG, average 24hour glucose and the time spent with glucose between 3.9 and $7.8 \mathrm{mmol} / \mathrm{L}$ over a 24 -hour period. However, exenatide therapy was associated with significantly lower twohour PPG, average 24-hour glucose and more time spent with glucose between 3.9 and $7.8 \mathrm{mmol} / \mathrm{l}(P=<0.05)$. As recently observed in other studies, postprandial intact GLP-1 levels were reduced with exenatide therapy and increased with sitagliptin. Postprandial glucogon levels were reduced significantly more by exenatide therapy than sitagliptin $(P=<0.005)$ [32].

To summarize, there appear to be important mechanistic differences between exenatide and sitagliptin in these short term studies. Longer term direct head to head comparative studies are needed to ascertain the durability and effects of these differences on the glycemic outcomes. Also, it is important to ascertain if these differential effects extend to the other agents in the respective incretin based classes.

\section{Head to head RCTs of GLP-1 agonists and DPP-4 inhibitors}

The effect of these physiological differences were studied in four further randomized studies, each lasting for 24 to 26 weeks with one of them having a further extension period of 26 weeks (Table 1 ).

The 1860-Lira-DPP-4 study was an open label parallel group trial comparing liraglutide $(1.8 \mathrm{mg}$ and $1.2 \mathrm{mg}$ ) against sitagliptin $(100 \mathrm{mg})$, all in combination with metformin in patients treated with T2DM [33]. Recently, the outcomes of an open label extension for a further 26 weeks in patients completing the 1860-Lira-DPP-4 study have been published [34]. Therefore, the 1860-Lira-DPP-4 study comparing liraglutide 1.2 and $1.8 \mathrm{mg}$ with sitagliptin $100 \mathrm{mg}$ is the longest head to head comparative study between a GLP-1 agonist and DPP-4 inhibitor.

The DURATION 2 (Diabetes Therapy Utilization: Researching changes in A1c, weight and other factors Through Intervention with exenatide ONce weekly) and DURATION 4 trials involved comparison of a recently approved once weekly preparation of exenatide (Exenatide QW $2 \mathrm{mg}$ ) against sitagliptin (100 mg/day) [35-37]. The DURATION 4 was a monotherapy study while the DURATION 2 involved combination therapy with metformin and also had a third arm involving pioglitazone [37]. In the T-emerge 4-trial, taspoglutide, a once weekly GLP-1 analogue, was compared against sitagliptin in a double-dummy 24 week trial [38]. Taspoglutide was suspended in the late stages of development due to concerns regarding hypersensitivity reactions and gastrointestinal side effects [39].

\section{Changes in $\mathrm{HbA} 1 \mathrm{c}$}

In the 1860-Lira-DPP-4 study, mean baseline HbA1c was $8.4 \%$. A greater reduction in HbA1c was seen with liraglutide $1.2 \mathrm{mg}(-1.24 \%$; $95 \% \mathrm{CI},-1.37$ to -1.11$)$ and $1.8 \mathrm{mg}$ $(-1.5 \%$; $95 \% \mathrm{CI},-1.63$ to -1.37$)$ compared with sitagliptin (-0.9\%; $95 \% \mathrm{CI},-1.03$ to -0.77$)$. Estimated mean treatment differences for liraglutide at $1.2 \mathrm{mg}$ and $1.8 \mathrm{mg}$ doses compared to $100 \mathrm{mg}$ sitagliptin were $-0.34 \%$ for 1.2 $\mathrm{mg}(P<0.0001)$ and $-0.6 \%$ for $1.8 \mathrm{mg}(P=<0.0001)$. The reduction of $0.9 \%$ in $\mathrm{HbA} 1 \mathrm{c}$ with sitagliptin in the 1860 Lira-DPP-4 study is one of the better results achieved in a trial with sitagliptin [33].

During the extension phase of the 1860-Lira-DPP-4 study, mean HbA1c improvement with liraglutide $1.8 \mathrm{mg}$ and $1.2 \mathrm{mg}$, and sitagliptin at 52 weeks from baseline was $1.29 \%, 1.51 \%$ and $0.88 \%$, respectively. Thus liraglutide produced a significant and sustained reduction in HbA1c compared to sitagliptin at 52 weeks. The improvement in glycemic control with liraglutide was irrespective of baseline HbA1c [34].

In the DURATION-2 study, the mean baseline HbA1c was $8.6 \%$. Exenatide QW therapy resulted in a significant reduction in $\mathrm{HbA} 1 \mathrm{c}$ compared with sitagliptin $(-1.5 \%$ versus $-0.9 \%, P=<0.0001)$. Significant HbA1c improvement was noted within four weeks of exenatide QW therapy and within six weeks of sitagliptin therapy. In a subgroup of patients with a basal HbA1c less than 9\%, exenatide QW therapy resulted in significant improvements (mean baseline HbA1c $7.8 \%$, change in HbA1c -1.1\%) in comparison to sitagliptin (mean baseline HbA1c $7.7 \%$, change in HbA1c - 0.5\%) [35]. It is well appreciated that the relative contribution of PPG in overall diurnal hyperglycemia is higher in well controlled subjects with diabetes [40]. Further improvement in HbA1c in a subgroup of well controlled patients during the DURATION-2 study therefore suggests underlying improvements in PPG, although PPG was not measured in the study.

In the T-emerge 4 Trial, taspoglutide $10 \mathrm{mg}$ and $20 \mathrm{mg}$ has been shown to improve HbA1c significantly more than that achieved with sitagliptin $(-1.3 \%,-1.23 \%$ and $-0.89 \%$ improvement from baseline with taspoglutide 20 $\mathrm{mg}, 10 \mathrm{mg}$ and sitagliptin, respectively; $P<0.001$ for both doses of taspoglutide against sitagliptin). The mean baseline HbA1c across the treatment arms ranged from $7.95 \%$ to $8.03 \%$ in this study [38]. 
In the DURATION-4 trial 26 weeks monotherapy with exenatide QW reduced HbA1c by $1.5 \%$ from baseline as opposed to a $1.2 \%$ reduction with sitagliptin [37].

\section{Changes in glucose levels}

In the 1860-Lira-DPP-4 study, the mean reduction in FPG was greater with liraglutide compared to sitagliptin (mean of $-2.14 \mathrm{mmol} / \mathrm{L}$ with liraglutide $1.8 \mathrm{mg},-1.87 \mathrm{mmo} / \mathrm{L}$ with liraglutide $1.2 \mathrm{mg}$ and $-0.83 \mathrm{mmol} / \mathrm{L}$ with sitagliptin 100 $\mathrm{mg}$ ) [33]. Improvements and differences in FPG were sustained during the extension phase of the 1860-Lira-DPP-4 study. At 52 weeks, the mean reduction in FPG was -2.04 $\mathrm{mmol} / \mathrm{l},-1.71 \mathrm{mmol} / \mathrm{l}$ and $-0.59 \mathrm{mmol} / \mathrm{l}$ with liraglutide 1.8 $\mathrm{mg}, 1.2 \mathrm{mg}$ and sitagliptin $100 \mathrm{mg}$, respectively [34]. Treatment differences between sitagliptin and liraglutide remained statistically significant for both doses $(P<0.0001)$. The improvement in mean FPG was twofold greater with exenatide QW treated patients in comparison to sitagliptin treated patients in the DURATION-2 trial $(-1.8 \mathrm{mmol} / \mathrm{L}$ versus $-0.9 \mathrm{mmol} / \mathrm{L}$, respectively) [35]. Changes in PPG levels were not assessed in these head to head trials. In contrast to short term mechanistic studies, there was a significant difference in FPG in these head to head comparative trials conducted over a longer period of time. Differences in efficacy and tolerability among studied GLP1 analogue and DPP-4 inhibitor in the 1860-Lira-DPP-4 and DURATION-2 study are summarized in Table 3. In the DURATION 4 trial exenatide QW significantly reduced fasting glucose at 16 and 26 weeks as well 7 point self-monitoring blood glucose (SMBG) profiles compared to sitagliptin [37].

\section{Changes in body weight}

In the 1860-Lira-DPP-4 study group trial, the mean weight loss was significantly greater with liraglutide than sitagliptin. The estimated mean weight differences were $-2.4 \mathrm{~kg}$ (95\% CI-3.14 to -1.70) for $1.8 \mathrm{mg}$ liraglutide versus sitagliptin, and $-1.90 \mathrm{~kg}(-2.61$ to -1.18$)$ for $1.2 \mathrm{mg}$ liraglutide versus sitagliptin. Liraglutide at both doses produced a greater reduction in waist circumference but there were no differences in waist to hip ratio [33]. During the 1860Lira DPP4 extension phase, weight loss achieved during the first 26 weeks was sustained at 52 weeks. At the end of the study period mean weight loss with liraglutide $1.8 \mathrm{mg}$, $1.2 \mathrm{mg}$ and sitagliptin was $3.68 \mathrm{~kg}, 2.78 \mathrm{~kg}$ and $1.16 \mathrm{~kg}$, respectively with mean treatment differences between the agents remaining statistically significant $(P<0.0001)$ [34].

In the DURATION 2 trial, the differences in weight loss became apparent by 4 weeks and by week 26 , weight loss with exenatide QW ( $-2.3 \mathrm{~kg}, 95 \% \mathrm{CI}-2.9$ to -1.7$)$ was significantly greater compared to sitagliptin $(-0.8 \mathrm{~kg}, 95 \%$ CI -1.4 to -0.1$)$. The mean treatment difference was -1.5 $\mathrm{kg}(95 \% \mathrm{CI}-2.4$ to -0.7 , adjusted $P=0.0002)$ for exenatide QW versus sitagliptin. In terms of absolute numbers, more than $75 \%(n=123)$ of patients on once weekly exenatide lost bodyweight compared with $61 \%(\mathrm{n}=101)$ of those on sitagliptin [35]. Weight loss with taspoglutide $10 \mathrm{mg}$ and $20 \mathrm{mg}$ once weekly dose was $1.23 \mathrm{~kg}$ and 2.54 $\mathrm{kg}$, respectively, in comparison to $0.55 \mathrm{~kg}$ weight loss seen with sitagliptin over the 24 week study period [38]. In the DURATION 4 trial, treatment with exenatide QW reduced body weight significantly compared to sitagliptin (weight loss $2 \mathrm{~kg}$ versus $0.8 \mathrm{~kg}, P=<0.001$ ) [37].

The effect of differential calorie intake and the reduced gastric emptying noticed during short term mechanistic studies between agents in the GLP-1 analogue and DPP4 inhibitors groups probably explain the differential weight loss in favor of GLP-1 agonists in the subsequent longer term head to head comparisons up to a one-year period.

\section{Changes in blood pressure and other metabolic parameters}

There was no significant difference observed for systolic blood pressure in the 1860-Lira-DPP-4 study group trial although both liraglutide and sitagliptin reduced the systolic blood pressure. Sitagliptin reduced diastolic blood pressure significantly compared to $1.8 \mathrm{mg}$ liraglutide but there was no significant difference compared to $1.2 \mathrm{mg}$ liraglutide. The overall effect on the blood pressure with either drug was small [33]. During the 1860-Lira-DPP-4 study extension there were no significant differences noted with liraglitide or sitaglipin except reduction of systolic blood pressure with $1.8 \mathrm{mg}$ liraglutide. Other large clinical studies with liraglutide have shown consistent reductions in systolic blood pressure [41-46]. During the DURATION-2 trial the exenatide QW treated group had significantly lower systolic blood pressure at 26 weeks compared to sitagliptin. The mean difference was $-4 \mathrm{~mm} \mathrm{Hg}$ (CI -6 to $-1 \mathrm{~mm}$ of $\mathrm{Hg}$ ) between once a week exenatide and daily sitagliptin. There were no significant differences in the levels of diastolic blood pressure [35]. Similar to liraglutide, large clinical trials with exenatide have shown favorable effects on blood pressure [47]. DPP-4 inhibitors, on the other hand, have shown variable effects on blood pressure [48-50].

The 1860-Lira-DPP-4 study did not observe any significant differences with lipid profile except a significant reduction in total cholesterol from baseline with the 1.8 mg liraglutide dose compared to sitagliptin. In the DURATION 2 trial neither exenatide nor sitagliptin had any significant effect on the lipid profile.

\section{Hypoglycemia}

In the DURATION-2 trial there were no reported major hypoglycemic episodes. Minor hypoglycemia episodes were similar with the exenatide QW and sitagliptin [35]. The 1860-Lira-DPP-4 study reported a single episode of major 
Table 3 Comparison of GLP-1 analogues in DPP-4 inhibitors- data from fully published RCTs [33-35,37].

\begin{tabular}{|c|c|c|c|c|c|c|c|}
\hline \multirow{2}{*}{$\begin{array}{l}\text { Study } \\
\text { Agent }\end{array}$} & \multicolumn{3}{|c|}{ The 1860- Lira DPP-4 study (52 weeks) } & \multicolumn{2}{|c|}{$\begin{array}{l}\text { DURATION } 2 \text { ( } 26 \text { weeks) - } \\
\text { Add on therapy to Metformin }\end{array}$} & \multicolumn{2}{|c|}{$\begin{array}{l}\text { DURATION } 4 \text { (26 weeks) - } \\
\text { Monotherapy }\end{array}$} \\
\hline & $\begin{array}{l}\text { Liraglutide } .8 \\
\mathrm{mg} / \text { day }\end{array}$ & $\begin{array}{l}\text { Liraglutide } 1.2 \\
\mathrm{mg} / \text { day }\end{array}$ & $\begin{array}{l}\text { Sitagliptin } 100 \\
\text { mg/day }\end{array}$ & $\begin{array}{l}\text { Exenatide } \\
\text { QW2 mg/ } \\
\text { weekly }\end{array}$ & $\begin{array}{l}\text { Sitagliptin } 100 \\
\text { mg/day }\end{array}$ & $\begin{array}{l}\text { Exenatide } \\
\text { QW2 mg/ } \\
\text { weekly }\end{array}$ & $\begin{array}{l}\text { Sitagliptin } 100 \\
\text { mg/day }\end{array}$ \\
\hline Number of patients & 225 & 221 & 219 & 160 & 166 & 248 & 163 \\
\hline Mean baseline HbA1c (\%) & $8.4(0.8)$ & $8.4(0.7)$ & $8.5(0.7)$ & $8.6(1.2)$ & $8.5(1.2)$ & $8.4-8.6$ & $8.4-8.6$ \\
\hline Change in $\mathrm{HbA} 1 \mathrm{c}(\%)$ & -1.51 & -1.29 & -0.88 & -1.5 & -0.9 & -1.53 & $\begin{array}{c}-1.15 \\
(P=<0.001)\end{array}$ \\
\hline $\begin{array}{l}\text { Mean treatment difference in } \\
\mathrm{HbA1c} \text { with DPP-4 inhibitor }\end{array}$ & $\begin{array}{c}-0.63 \\
(P<0.0001)\end{array}$ & $\begin{array}{c}-0.4 \\
(P<0.0001)\end{array}$ & - & $\begin{array}{c}-0.6 \\
(P<0.0001)\end{array}$ & - & - & - \\
\hline $\begin{array}{l}\text { Mean baseline FPG } \\
(\mathrm{mmol} / \mathrm{L})\end{array}$ & $10.1(2.4)$ & $9.9(2.4)$ & $10.0(2.0)$ & $9.2(2.9)$ & $9.1(2.5)$ & 9.7 to 9.9 & 9.7 to 9.9 \\
\hline $\begin{array}{l}\text { Change in FPG } \\
(\mathrm{mmol} / \mathrm{L})\end{array}$ & -2.04 & -1.71 & -0.59 & -1.8 & -0.9 & -2.3 & $\begin{aligned} & -1.1 \\
(P= & <0.001)\end{aligned}$ \\
\hline $\begin{array}{l}\text { Mean treatment difference in } \\
\text { FPG with DPP-4 inhibitor }\end{array}$ & $\begin{aligned} & -1.45 \\
(P & <0.0001)\end{aligned}$ & $\begin{aligned} & -1.13 \\
(P & <0.0001)\end{aligned}$ & - & $\begin{array}{c}-0.9 \\
(P<0.0001)\end{array}$ & - & - & - \\
\hline Baseline weight (Kg) & $93.7(18.4)$ & $94.6(18.1)$ & $93.1(18.9)$ & $89(20)$ & $87(20)$ & 85.9 to 88.6 & 85.9 to 88.6 \\
\hline Change in weight (Kg) & -3.68 & -2.78 & -1.16 & -2.3 & -0.8 & -2.0 & $\begin{aligned} & -0.8 \\
(P & <0.001)\end{aligned}$ \\
\hline $\begin{array}{l}\text { Mean treatment differences } \\
\text { in weight with DPP-4 } \\
\text { inhibitor }\end{array}$ & $\begin{aligned} &-2.53 \\
&(P<0.0001)\end{aligned}$ & $\begin{aligned} & -1.62 \\
(P & <0.0001)\end{aligned}$ & - & $\begin{array}{c}\quad-1.5 \\
(P<0.0001)\end{array}$ & - & - & - \\
\hline Incidence of hypoglycemia & $\begin{array}{l}\text { 0.143episodes/ } \\
\text { patient/year }\end{array}$ & $\begin{array}{c}0.154 \\
\text { episodes/ } \\
\text { patient/year }\end{array}$ & $\begin{array}{c}0.137 \\
\text { episodes/ } \\
\text { patient/year }\end{array}$ & $1 \%$ & $3 \%$ & $5.2 \%$ & $3.1 \%$ \\
\hline Nausea Number (\%) & $60(27.5)$ & $40(21.7)$ & $12(5.5)$ & $38(24)$ & $16(10)$ & $11.3 \%$ & $3.7 \%$ \\
\hline Diarrhea Number (\%) & $27(12.4)$ & $20(9)$ & $14(6.4)$ & $29(18)$ & $16(10)$ & $10.9 \%$ & $5.5 \%$ \\
\hline
\end{tabular}

DDP-4, dipeptidyl peptidase 4; FPG, fasting plasma glucose; GLP-1, glucagon-like peptide 1; HbA1c, hemoglobulin A1c

hypoglycemia with $1.2 \mathrm{mg}$ liraglutide (blood glucose concentration of $3.6 \mathrm{mmol} / \mathrm{L}$ ). Minor hypoglycemia episodes were reported by similar proportions of participants treated with $1.8 \mathrm{mg}$ liraglutide (11 (5\%), 0.370 episodes per participant-year), $1.2 \mathrm{mg}$ liraglutide (12 (5\%), 0.178), and sitagliptin $(10(5 \%), 0.106)$ [33]. During the extension phase of the 1860-Lira DPP4 study, no episodes of major hypoglycemia occurred and the minor hypoglycemia events remained comparable during the whole 52-week study period [34]. The DURATION 4 trial did not report any major hypoglycemia episodes. An incidence of 5.2\% in the exenatide QW group versus $3.1 \%$ in the sitagliptin group was reported for unconfirmed hypoglycemia [51].

\section{Gastrointestinal side effects}

As noticed in short term mechanistic studies, all the longer term comparative RCTs showed more initial nausea and vomiting with GLP-1 agonists compared to DPP-4 inhibitors. In the 1860-Lira-DPP-4 study, nausea was more common with liraglutide $(21 \%$ to $27 \%)$ than with sitagliptin (5\%) at the beginning of the therapy but by the end of the trial, symptoms decreased to the level observed with sitagliptin $(<3 \%)$ and patients reported that nausea remained comparable during the extension period [33,34]. In the DURATION-2 trial nausea was more common with once a week exenatide ( $24 \%$ patients) compared to sitagliptin (10\% patients) [36]. The DURATION 4 trial reported $11.3 \%$ patients experiencing nausea on treatment with exenatide QW while vomiting was noted in $4.8 \%$ patients treated with exenatide QW compared to $1.8 \%$ patients in the siatgliptin group [51].

\section{Incretins and safety}

Cases of pancreatitis have been reported in the patients who were treated with agents in both classes of incretinbased therapies [52]. During the head to head comparison trials, no episode of pancreatitis was noticed during the first 26 weeks of the 1860-Lira-DPP4 study. However, an episode of mild non acute pancreatitis was reported during the extension period [34]. No cases of pancreatitis were reported during the DURATION-2 trial.

Large preclinical studies involving diabetic mice and rats have failed to show an association between GLP-1 agonists, such as exenatide and liraglutide, as well as the DPP4 inhibitor sitagliptin and pancreatitis [53,54]. Large cohort studies looking at the health care databases have not shown any association with the incretin-based therapies and pancreatitis [55,56]. A recently published large cohort study analyzed the rates of acute pancreatitis in diabetic subjects treated with exenatide, sitagliptin and 
other antidiabetic agents using data from the Medco National Integrated Database from January 2007 to June 2009. The risk of pancreatitis was high in patients with diabetes compared to patients without diabetes (adjusted hazard ratio 2.1 (95\% CI 1.7 to 2.5$)$ ), but there was no increased risk of pancreatitis seen in patients treated with exenatide or sitagliptin compared to patients who received other diabetic medications [57]. The available data do not support an association between incretin therapies and pancreatitis. Long term larger studies are needed to investigate this further.

Long term exposure to liraglutide has been shown to be associated with thyroid ' $C$ ' cell hyperplasia in rodents [58]. In contrast, monkeys and humans have much lower levels of GLP-1R expression, and prolonged administration of liraglutide at very high doses has not been shown to produce C-cell proliferation in monkeys. Data from long term studies, such as the 1860-Lira-DPP-4 trial, have not shown any increase in the mean calcitonin level, which is the marker of $C$ cell hyperplasia and medullary thyroid carcinoma, in patients treated with liraglutide $[33,59]$.

\section{Cardiovascular safety}

The large ongoing outcome trial LEADER (Liraglutide Effects and Actions in Diabetes, Evaluation of Cardiovascular Results) will investigate the safety profile of liraglutide in approximately 9,000 patients with T2DM. It will include patients with a high risk cardiovascular profile in a global setting [60]. EXSCEL (Exenatide Study of Cardiovascular Event Lowering) is a similar large study planned to investigate the safety of exenatideQW preparations. EXSCEL is a double-blind randomized, placebo controlled, multi-national superiority trial in patients with T2DM. It aims to compare the impact of including exenatide as part of usual care versus usual care without exenatide on major cardiovascular outcomes. A total of 9,500 patients will be recruited and will be followed for a minimum of four years [61]. TECOS (Trial Evaluating Cardiovascular Outcomes with Sitalgliptin) hopes to investigate safety and cardiovascular outcomes with sitagliptin. TECOS is a double-blind randomized, placebo controlled, multi-national trial in patients with T2DM. TECOS aims to compare the impact of adding sitagliptin as part of usual care versus usual care without sitagliptin on cardiovascular outcomes. A total of 14,000 patients will be followed for a minimum of three years [61].

\section{Patient reported outcome measures and satisfaction}

Diabetes mellitus, its treatment and its complications often affect a patient's quality of life [8]. Patient reported treatment outcomes may provide the data on health related quality of life as well information on patients' perceptions on efficacy, tolerability and preferences about a particular therapy. Higher patient satisfaction may indicate better compliance with the therapy [62-64].

In the 1860-Lira-DPP-4 study group open label trial, patients' treatment satisfaction was assessed using the Diabetes Treatment Satisfaction Questionnaire (DTSQ). The increase in patients' treatment satisfaction from baseline was significantly higher with $1.8 \mathrm{mg}$ liraglutide than with sitagliptin ( 4.35 versus $2.96, P=0.03$ ), but the increase with $1.2 \mathrm{mg}$ liraglutide versus sitagliptin was not significant. Patients reported significantly greater improvement in treatment satisfaction with liraglutide $1.8 \mathrm{mg}$ than sitagliptin on three items: 'current treatment' (difference = $0.35 ; P=0.01$ ), 'recommend' (difference $=0.41 ; P=0.003$ ) and 'continue' (difference $=0.44 ; P=0.01$ ). Patients perceived themselves less hyperglycemic on either of the doses of liraglutide compared to sitagliptin $(P<0.05)$. There was no difference between liraglutide and sitagliptin on DTSQ items relating to treatment convenience and flexibility, indicating that patients were no less satisfied with the injectable than with the oral agent [65].

There was no significant difference in all five domains of the IWQOL total score between exenatide once a weekly and sitagliptin (5.15 versus 4.56). A greater improvement in overall treatment satisfaction was recorded with exenatide than with sitagliptin (difference 1.61, $P=0.0406$ ). However, the DURATION 2 was a double dummy trial with all of the patients receiving a tablet as well as an injection. Hence, it is more difficult to tease out the differences between therapies [35].

In the double blind placebo controlled DURATION 4 trial there was no significant difference in weight-related quality of life, binge-eating behavior or health status between exenatide QW and sitagliptin monotherapy.

\section{Conclusions}

In the clinical trials, both types of incretin-based therapies are effective in improving hyperglycemia; however, as suggested by the proof of concept study, the magnitude of glycemic improvement was significantly higher with GLP$1 \mathrm{R}$ agonists and was consistent in the order of estimated mean treatment difference in HbA1c of $0.34 \%$ to $0.63 \%$ over and above that obtained with DPP-4 inhibitors. Greater HbA1c reduction with GLP-1agonists is probably due to pharmacological concentrations of free (non-albumin-bound) GLP-1 agonists [31,66]. DPP-4 inhibitors achieve two to three times increment in the native GLP concentration. However, several fold higher levels of GLP1 agonist leads to greater stimulation of GLP-1 receptor [66]. Similarly, there is also a significantly greater weight loss (estimated mean treatment difference of -1.5 to -2.53 $\mathrm{Kg}$ ) associated with GLP-1 agonists compared to DPP-4 inhibitors. This is most likely due to reduced calorie intake and central satiety effects. Although the differences in FPG were not evident during the initial short term proof of 
concept study, the longer term RCTs have consistently shown greater improvements in FPG with GLP-1 agonists as compared to DPP-4 inhibitors. Sitagliptin has a similar pharmacokinetic half-life to liraglutide (about 12 hours) but the increase in endogenous GLP-1 concentrations with DPP-4 inhibitors occurs mainly after meals. Thus, fasting concentrations of active GLP-1 remain fairly low overnight, so reductions in FPG concentrations with sitagliptin are low compared with liraglutide. While GLP-1 agonists are injected, DPP-4 inhibitors are taken orally and, although it is often stated that patients resist injectable therapies, published data suggest this is not by any means a universal finding. The results from the open label 1860 trial with liraglutide suggest patients were no less satisfied with injectable therapy compared to oral DPP-4 inhibitors and, in fact, were more satisfied in the $1.8 \mathrm{mg}$ liraglutide arm compared to sitagliptin [65].

In general, the efficacy and safety of the incretin based agents from both classes have been shown to be durable. Their safety with longer term use will be ascertained by currently ongoing outcome trials (LEADER, EXSCEL, and TECOS) $[60,61]$.

Similarly, although the currently marketed DPP-4 inhibitors appear to be comparable as a class regarding the degree of glycemic improvement, only sitagliptin was tested in these direct head to head comparisons. However, sitagliptin is the most widely prescribed DPP-4 inhibitor.

As with the other therapies, the selection of an incretin based agent for glycemic control in patients with T2DM should be individualized, taking into consideration the aims and intensity of glycemic improvement, tolerability of the therapy, the effect of such therapy on the various co-existing morbidities while assuring the therapy is acceptable and safe for patients in the longer term.

\section{Abbreviations \\ bid: twice a day; DPP-4 inhibitors: dipeptidylpeptidase-4 inhibitor; DTSQ: Diabetes Treatment Satisfaction Questionnaire; EMA: European Medicine Agency; EQ-5D: European Quality of Life - 5 Dimension; FDA: Food and Drug Administration; FPG: fasting plasma glucose; GIP: glucose-dependent insulinotropic peptide; GLP-1: glucagon like peptide 1; HbA1c: hemoglobin A1c; IGT: impaired glucose tolerance; PPG: postprandial glucose; RCT: randomized controlled trial; SMBG: self-monitoring blood glucose; SU: sulfonylureas; T2DM: type 2 diabetes mellitus;TZD: thiazolidinediones.}

\section{Authors' contributions}

KN and RK drafted the manuscript. MD and KK critically reviewed the manuscript. All authors read and approved the final manuscript.

\section{Competing interests}

KN and RK declare they have no competing interests. KK has acted as a consultant and speaker for Novartis, Novo Nordisk, Sanofi-Aventis, Lilly and Merck Sharp \& Dohme. He has received grants in support of investigator and investigator initiated trials from Novartis, Novo Nordisk, Sanofi-Aventis, Lilly, Pfizer, Boehringer Ingelheim and Merck Sharp \& Dohme. MJD has received funds for research, honoraria for speaking at meetings and has served on advisory boards for Lilly, Sanofi-Aventis, Merck Sharp \& Dohme and Novo Nordisk.

\section{Author details}

'Department of Diabetes and Endocrinology, University Hospitals of Leicester NHS Trust, Leicester Royal infirmary, Infirmary Square, Leicester LE1 5WW, UK. ${ }^{2}$ Department of Health Sciences, University of Leicester, 22-28 Princess Road West, Leicester LE1 6TP, UK. ${ }^{3}$ Diabetes Department, Department of Cardiovascular Sciences, University of Leicester, Leicester General Hospital, Gwendolen Road, Leicester, LE5 4WP, UK.

Received: 28 March 2012 Accepted: 30 November 2012 Published: 30 November 2012

\section{References}

1. Whiting DR, Guariguata L, Weil C, Shaw J: IDF diabetes atlas: global estimates of the prevalence of diabetes for 2011 and 2030. Diabetes Res Clin Pract 2011, 94:311-321.

2. Finucane MM, Stevens GA, Cowan MJ, Danaei G, Lin JK, Paciorek CJ, Singh GM, Gutierrez HR, Lu Y, Bahalim AN, Farzadfar F, Riley LM, Ezzati M: National, regional, and global trends in body-mass index since 1980: systematic analysis of health examination surveys and epidemiological studies with 960 country-years and 9.1 million participants. Lancet 2011 . 377:557-567.

3. National Obesity Observatory: National obesity observatory data. 2011 [http://www.noo.org.uk].

4. Daousi C, Casson IF, Gill GV, MacFarlane IA, Wilding JP, Pinkney JH: Prevalence of obesity in type 2 diabetes in secondary care: association with cardiovascular risk factors. Postgrad Med J 2006, 82:280-284.

5. Intensive blood-glucose control with sulphonylureas or insulin compared with conventional treatment and risk of complications in patients with type 2 diabetes (UKPDS 33). UK Prospective Diabetes Study (UKPDS) Group. Lancet 1998, 352:837-853.

6. Kahn SE, Haffner SM, Heise MA, Herman WH, Holman RR, Jones NP, Kravitz BG, Lachin JM, O'Neill MC, Zinman B, Viberti G: Glycemic durability of rosiglitazone, metformin, or glyburide monotherapy. $N$ Engl I Med 2006, 355:2427-2443.

7. Ross SA, Dzida G, Vora J, Khunti K, Kaiser M, Ligthelm RJ: Impact of weight gain on outcomes in type 2 diabetes. Curr Med Res Opin 2011, 27:1431-1438.

8. Jacobson AM: Impact of improved glycemic control on quality of life in patients with diabetes. Endocr Pract 2004, 10:502-508.

9. Blonde L, Montanya E: Comparison of liraglutide versus other incretinrelated anti-hyperglycaemic agents. Diabetes Obes Metab 2012, 14(Suppl 2):20-32.

10. Nauck MA: Incretin-based therapies for type 2 diabetes mellitus: properties, functions, and clinical implications. Am J Med 2011, 124:S3-18.

11. Madsbad S, Krarup T, Deacon CF, Holst JJ: Glucagon-like peptide receptor agonists and dipeptidyl peptidase-4 inhibitors in the treatment of diabetes: a review of clinical trials. Curr Opin Clin Nutr Metab Care 2008, 11:491-499.

12. Baggio LL, Drucker DJ: Biology of incretins: GLP-1 and GIP. Gastroenterology 2007, 132:2131-2157.

13. Drucker DJ, Nauck MA: The incretin system: glucagon-like peptide-1 receptor agonists and dipeptidyl peptidase- 4 inhibitors in type 2 diabetes. Lancet 2006, 368:1696-1705.

14. Drucker DJ: Enhancing incretin action for the treatment of type 2 diabetes. Diabetes Care 2003, 26:2929-2940.

15. Zander M, Madsbad S, Madsen JL, Holst JJ: Effect of 6-week course of glucagon-like peptide 1 on glycaemic control, insulin sensitivity, and beta-cell function in type 2 diabetes: a parallel-group study. Lancet 2002, 359:824-830.

16. Toft-Nielsen MB, Damholt MB, Madsbad S, Hilsted LM, Hughes TE, Michelsen BK Holst JJ: Determinants of the impaired secretion of glucagon-like peptide-1 in type 2 diabetic patients. J Clin Endocrinol Metab 2001, 86:3717-3723.

17. Vilsboll T, Krarup T, Deacon CF, Madsbad S, Holst JJ: Reduced postprandial concentrations of intact biologically active glucagon-like peptide 1 in type 2 diabetic patients. Diabetes 2001, 50:609-613.

18. Kjems LL, Holst JJ, Volund A, Madsbad S: The influence of GLP-1 on glucose-stimulated insulin secretion: effects on beta-cell sensitivity in type 2 and nondiabetic subjects. Diabetes 2003, 52:380-386. 
19. Bagger JI, Knop FK, Lund A, Vestergaard H, Holst JJ, Vilsboll T: Impaired regulation of the incretin effect in patients with type 2 diabetes. $J$ Clin Endocrinol Metab 2011, 96:737-745.

20. Vollmer K, Holst JJ, Baller B, Ellrichmann M, Nauck MA, Schmidt WE, Meier JJ: Predictors of incretin concentrations in subjects with normal, impaired, and diabetic glucose tolerance. Diabetes 2008, 57:678-687.

21. Nauck MA, Vardarli I, Deacon CF, Holst JJ, Meier JJ: Secretion of glucagonlike peptide-1 (GLP-1) in type 2 diabetes: what is up, what is down? Diabetologia 2011, 54:10-18.

22. Hildebrandt M, Reutter W, Arck P, Rose M, Klapp BF: A guardian angel: the involvement of dipeptidyl peptidase IV in psychoneuroendocrine function, nutrition and immune defence. Clin Sci (Lond) 2000, 99:93-104.

23. Kieffer TJ, McIntosh CH, Pederson RA: Degradation of glucose-dependent insulinotropic polypeptide and truncated glucagon-like peptide 1 in vitro and in vivo by dipeptidyl peptidase IV. Endocrinology 1995, 136:3585-3596.

24. Vilsboll T, Agerso H, Krarup T, Holst JJ: Similar elimination rates of glucagon-like peptide- 1 in obese type 2 diabetic patients and healthy subjects. J Clin Endocrinol Metab 2003, 88:220-224.

25. Hendry J: FDA approves exenatide. DOC News 2011, 2005:1-6.

26. Eng J, Kleinman WA, Singh L, Singh G, Raufman JP: Isolation and characterization of exendin-4, an exendin-3 analogue, from Heloderma suspectum venom. Further evidence for an exendin receptor on dispersed acini from guinea pig pancreas. J Biol Chem 1992, 267:7402-7405.

27. Agerso $H$, Jensen LB, Elbrond B, Rolan P, Zdravkovic M: The pharmacokinetics, pharmacodynamics, safety and tolerability of NN2211, a new long-acting GLP-1 derivative, in healthy men. Diabetologia 2002, 45:195-202.

28. Drucker DJ, Buse JB, Taylor K, Kendall DM, Trautmann M, Zhuang D, Porter L, DURATION-1 Study Group: Exenatide once weekly versus twice daily for the treatment of type 2 diabetes: a randomised, open-label, non-inferiority study. Lancet 2008, 372:1240-1250.

29. Januvia [prescribing information]. Whitehouse Station, NJ: Merck \& Co., Inc; 2010.

30. Drucker DJ, Nauck MA: The incretin system: glucagon-like peptide-1 receptor agonists and dipeptidyl peptidase-4 inhibitors in type 2 diabetes. Lancet 2006, 368:1696-1705.

31. DeFronzo RA, Okerson T, Viswanathan P, Guan X, Holcombe JH, MacConell $L$ : Effects of exenatide versus sitagliptin on postprandial glucose, insulin and glucagon secretion, gastric emptying, and caloric intake: a randomized, cross-over study. Curr Med Res Opin 2008, 24:2943-2952.

32. Berg JK, Shenouda SK, Heilmann CR, Gray AL, Holcombe JH: Effects of exenatide twice daily versus sitagliptin on 24-hour glucose glucoregulatory, and hormonal measures: a randomized, double-blind, crossover study. Diabetes Obes Metab 2011, 13:982-989.

33. Pratley RE, Nauck M, Bailey T, Montanya E, Cuddihy R, Filetti S, Thomsen AB, Søndergaard RE, Davies M, 1860-LIRA-DPP-4 Study Group: Liraglutide versus sitagliptin for patients with type 2 diabetes who did not have adequate glycaemic control with metformin: a 26-week, randomised, parallel-group, open-label trial. Lancet 2010, 375:1447-1456.

34. Pratley R, Nauck M, Bailey T, Montanya E, Cuddihy R, Filetti S Garber A, Thomsen AB, Hartvig H, Davies M, 1860-LIRA-DPP-4 Study Group: One year of liraglutide treatment offers sustained and more effective glycaemic control and weight reduction compared with sitagliptin, both in combination with metformin, in patients with type 2 diabetes: a randomised, parallel-group, open-label trial. Int J Clin Pract 2011, 65:397-407.

35. Bergenstal RM, Wysham C, MacConell L, Malloy J, Walsh B, Yan P, Wilhelm K, Malone J, Porter LE, DURATION-2 Study Group: Efficacy and safety of exenatide once weekly versus sitagliptin or pioglitazone as an adjunct to metformin for treatment of type 2 diabetes (DURATION-2): a randomised trial. Lancet 2010, 376:431-439.

36. Lilly Newsroom. 2011.

37. Russell-Jones D, Cuddihy RM, Hanefeld M, Kumar A, Gonzalez JG, Chan M, Wolka AM, Boardman MK, DURATION-4 Study Group: Efficacy and safety of exenatide once weekly versus metformin, pioglitazone, and sitagliptin used as monotherapy in drug-naive patients with type 2 diabetes (DURATION-4): a 26-week double-blind study. Diabetes Care 2012, 35:252-258.
38. Bergenstal R, Forti A, Chiasson J, Woloschak M, Boldrin M, Leiter L, Balena R: Once weekly taspoglutide, a human GLP-1 analog, is superior to sitagliptin in improving glycemic control and weight loss in patients with type 2 diabetes (T2D): results from the T-emerge 4 trial. Diabetes 2010, 59(Suppl 1):58-OR

39. Nordqvist C: Experimental diabetes drug taspoglutide late-stage trials suspended. Medical News Today 2011 [http://www.medicalnewstoday.com/ articles/200893.php].

40. Monnier L, Lapinski H, Colette C: Contributions of fasting and postprandial plasma glucose increments to the overall diurnal hyperglycemia of type 2 diabetic patients: variations with increasing levels of $\mathrm{HbA}(1 \mathrm{c})$. Diabetes Care 2003, 26:881-885.

41. Buse JB, Rosenstock J, Sesti G, Schmidt WE, Montanya E, Brett JH, Zychma M, Blonde L, LEAD-6 Study Group: Liraglutide once a day versus exenatide twice a day for type 2 diabetes: a 26-week randomised, parallel-group, multinational, open-label trial (LEAD-6). Lancet 2009, 374:39-47.

42. Garber A, Henry RR, Ratner R, Hale P, Chang CT, Bode B: Liraglutide, a once-daily human glucagon-like peptide 1 analogue, provides sustained improvements in glycaemic control and weight for 2 years as monotherapy compared with glimepiride in patients with type 2 diabetes. Diabetes Obes Metab 2011, 13:348-356.

43. Marre M, Shaw J, Brandle M, Bebakar WM, Kamaruddin NA, Zdravkovic M, Le Thi TD, Colagiuri S, LEAD-1 SU study group: Liraglutide, a once-daily human GLP-1 analogue, added to a sulphonylurea over 26 weeks produces greater improvements in glycaemic and weight control compared with adding rosiglitazone or placebo in subjects with Type 2 diabetes (LEAD-1 SU). Diabet Med 2009, 26:268-278.

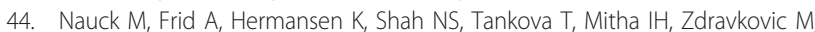
Düring $M$, Matthews DR, LEAD-2 Study Group: Efficacy and safety comparison of liraglutide, glimepiride, and placebo, all in combination with metformin, in type 2 diabetes: the LEAD (liraglutide effect and action in diabetes)-2 study. Diabetes Care 2009, 32:84-90

45. Russell-Jones D, Vaag A, Schmitz O, Sethi BK, Lalic N, Antic S, Zdravkovic M, Ravn GM, Simó R: Liraglutide vs insulin glargine and placebo in combination with metformin and sulfonylurea therapy in type 2 diabetes mellitus (LEAD-5 met+SU): a randomised controlled trial. Diabetologia 2009, 52:2046-2055.

46. Zinman B, Gerich J, Buse JB, Lewin A, Schwartz S, Raskin P Hale PM, Zdravkovic M, Blonde L, LEAD-4 Study Investigators: Efficacy and safety of the human glucagon-like peptide- 1 analog liraglutide in combination with metformin and thiazolidinedione in patients with type 2 diabetes (LEAD-4 Met+TZD). Diabetes Care 2009, 32:224-1230.

47. Okerson T, Yan P, Stonehouse A, Brodows R: Effects of exenatide on systolic blood pressure in subjects with type 2 diabetes. Am J Hypertens 2010, 23:34-339.

48. Neumiller JJ: Differential chemistry (structure), mechanism of action, and pharmacology of GLP-1 receptor agonists and DPP-4 inhibitors. J Am Pharm Assoc (2003) 2009, 49(Suppl 1):S16-S29.

49. Bosi E, Camisasca RP, Collober C, Rochotte E, Garber AJ: Effects of vildagliptin on glucose control over 24 weeks in patients with type 2 diabetes inadequately controlled with metformin. Diabetes Care 2007, 30:890-895.

50. Lovshin JA, Drucker DJ: Incretin-based therapies for type 2 diabetes mellitus. Nat Rev Endocrinol 2009, 5:262-269.

51. Russell-Jones D, Cuddihy RM, Hanefeld M, Kumar A, Gonzalez JG, Chan M, Wolka AM, Boardman MK, DURATION-4 Study Group: Efficacy and safety of exenatide once weekly versus metformin, pioglitazone, and sitagliptin used as monotherapy in drug-naive patients with type 2 diabetes (DURATION-4): a 26-week double-blind study. Diabetes Care 2012, 35:252-258.

52. Anderson SL, Trujillo JM: Association of pancreatitis with glucagon-like peptide-1 agonist use. Ann Pharmacother 2010, 44:904-909.

53. Tatarkiewicz K, Smith PA, Sablan EJ, Polizzi CJ, Aumann DE, Villescaz C, Hargrove DM, Gedulin BR, Lu MG, Adams L, Whisenant T, Roy D, Parkes DG: Exenatide does not evoke pancreatitis and attenuates chemically induced pancreatitis in normal and diabetic rodents. Am J Physiol Endocrinol Metab 2010, 299:E1076-E1086.

54. Engel SS, Williams-Herman DE, Golm GT, Clay RJ, Machotka SV, Kaufman KD Goldstein BJ: Sitagliptin: review of preclinical and clinical data regarding incidence of pancreatitis. Int J Clin Pract 2010, 64:984-990. 
55. Drucker DJ, Sherman SI, Bergenstal RM, Buse JB: The safety of incretinbased therapies-review of the scientific evidence. $J$ Clin Endocrinol Metab 2011, 96:2027-2031.

56. Dore DD, Bloomgren GL, Wenten M, Hoffman C, Clifford CR, Quinn SG, Braun DK, Noel RA, Seeger JD: A cohort study of acute pancreatitis in relation to exenatide use. Diabetes Obes Metab 2011, 13:559-566.

57. Garg R, Chen W, Pendergrass M: Acute pancreatitis in type 2 diabetes treated with exenatide or sitagliptin: a retrospective observational pharmacy claims analysis. Diabetes Care 2010, 33:2349-2354.

58. Bjerre KL, Madsen LW, Andersen S, Almholt K, de Boer AS, Drucker DJ, Gotfredsen C, Egerod FL, Hegelund AC, Jacobsen H, Jacobsen SD, Moses AC, Mølck AM, Nielsen HS, Nowak J, Solberg H, Thi TD, Zdravkovic M, Moerch U: Glucagon-like peptide-1 receptor agonists activate rodent thyroid C-cells causing calcitonin release and C-cell proliferation. Endocrinology 2010, 151:1473-1486.

59. Parks $M$, Rosebraugh $C$ : Weighing risks and benefits of liraglutide-the FDA's review of a new antidiabetic therapy. N Engl J Med 2010, 362:774-777.

60. Rossi MC, Nicolucci A: Liraglutide in type 2 diabetes: from pharmacological development to clinical practice. Acta Biomed 2009, 80:93-101

61. Fonseca VA: Ongoing clinical trials evaluating the cardiovascular safety and efficacy of therapeutic approaches to diabetes mellitus. Am J Cardiol 2011, 108:52B-58B.

62. Peyrot M, Rubin RR: How does treatment satisfaction work?: modeling determinants of treatment satisfaction and preference. Diabetes Care 2009, 32:1411-1417.

63. Nicolucci A, Cucinotta D, Squatrito S, Lapolla A, Musacchio N, Leotta S, Bulotta A, Nicoziani P, Coronel G, QuoLITy Study Group: Clinical and socioeconomic correlates of quality of life and treatment satisfaction in patients with type 2 diabetes. Nutr Metab Cardiovasc Dis 2009, 19:45-53.

64. Bradley C, Speight J: Patient perceptions of diabetes and diabetes therapy: assessing quality of life. Diabetes Metab Res Rev 2002, 18(Suppl 3):S64-S69.

65. Davies M, Pratley R, Hammer M, Thomsen AB, Cuddihy R: Liraglutide improves treatment satisfaction in people with Type 2 diabetes compared with sitagliptin, each as an add on to metformin. Diabet Med 2011, 28:333-337.

66. Degn KB, Juhl CB, Sturis J, Jakobsen G, Brock B, Chandramouli V, Rungby J, Landau BR, Schmitz O: One week's treatment with the long-acting glucagon-like peptide 1 derivative liraglutide (NN2211) markedly improves 24-h glycemia and alpha- and beta-cell function and reduces endogenous glucose release in patients with type 2 diabetes. Diabetes 2004, 53:1187-1194.

Pre-publication history

The pre-publication history for this paper can be accessed here: http://www.biomedcentral.com/1741-7015/10/152/prepub

doi:10.1186/1741-7015-10-152

Cite this article as: Nisal et al:: Comparison of efficacy between incretinbased therapies for type 2 diabetes mellitus. BMC Medicine 2012 10:152.

\section{Submit your next manuscript to BioMed Central and take full advantage of:}

- Convenient online submission

- Thorough peer review

- No space constraints or color figure charges

- Immediate publication on acceptance

- Inclusion in PubMed, CAS, Scopus and Google Scholar

- Research which is freely available for redistribution

Submit your manuscript at www.biomedcentral.com/submit
Biomed Central 